\title{
A dramaturgia como elemento formador de repertório do palhaço
}

The dramaturgy as a shaping element of the clown's repertoire

Pedro Eduardo da Silva ${ }^{1}$

1.

Mestre em artes pela Universidade Estadual Paulista "Júlio de Mesquita Filho" (UNESP). ORCID: http://orcid.org/ 0000-0001-7576-1945 . Contato: edusilva1965@gmail.com Pimenta - servem como guia para observarmos como a teatralidade adquirida no ambiente circense por meio do circo-teatro se transposta para a dramaturgia do palhaço. As pesquisas do dramaturgo e diretor teatral Carlos Alberto Soffredini e de Fernando Bolognese, juntamente com minhas experiências, destacam a importância do circo-teatro na estruturação da poética do palhaço.

Palavras-chave: Palhaço. Formação. Treinamento. Clown.

Circo.

\section{ABSTRACT}

The careers of two circus clowns - Roger Avanzi and Arlindo Pimenta - serve as a guide to observe how the theatricality acquired in the circus environment through the circus-theater is transposed into clown drama. The researches of the playwright and theater director Carlos Alberto Soffredini and Fernando Bolognese, together with my experiences, highlight the importance of circus theater in structuring the clown's poetics.

Keywords: Clown. Education. Training. Clown. Circus. 
O repertório circense é mnemônico, transmitido através das sucessivas gerações familiares. Entre as companhias há uma incessante troca de informações, com as consequentes alterações. A dramaturgia cômica circense (especialmente os esquetes) apóia-se em roteiros sucintos, motivos gerais que se prestam à improvisação e à criatividade dos artistas, especialmente dos cômicos. A eficácia da dramaturgia, portanto, obedece à criatividade de cada palhaço (BOLOGNESI, 2003, p. 172).

A arte teatral é muito presente na cultura circense, uma essência que se manifesta em todos os momentos e números do espetáculo: da abertura, com a eloquente narrativa do Mestre de Pista sobre os números que virão, passando pelas entradas e reprises cômicas dos palhaços e finalizando com palavras emocionantes que valorizam a presença do "distinto público". É possível afirmar que a ação dramática foi (e será) construída com fortes embasamentos teatrais que norteiam as performances dos artistas circenses de diversas técnicas e linguagens.

No caso dos artistas circenses Arlindo Pimenta (palhaço Pimenta) e Roger Avanzi (palhaço Picolino 2), temos a formação direta ocasionada pelo circo-teatro, que ofereceu técnicas e experiências que foram transpostas para o trabalho de palhaço. O "dom da palavra" é desenvolvido por meio das inúmeras montagens e apresentações do repertório que esses circos itinerantes se prestavam a oferecer para um público diversificado e ansioso pelos encontros artísticos e estimulantes que os circos propiciavam.

O trabalho dos ensaiadores da época não era apenas o de montar uma peça; esses artistas eram os responsáveis por manter a estética popular dessas encenações e também por estruturar a formação dos atores que encenavam as peças. $O$ raciocínio teatral apreendido com as experiências dessas montagens foi diretamente aplicado nas entradas e reprises cômicas.

O circo-teatro, tanto em seus dramas quanto comédias, utilizou uma tipologia para estruturação das personagens de suas peças, tipos que eram densamente entendidos e encenados pelos atores circenses. Nas narrativas de Roger Avanzi e Tabajara Pimenta (filho de Arlindo Pimenta que foi malabarista e gerente de vários circos) encontramos inúmeros fatos relacionados a ensaios e encenações que corroboram o peso da formação teatral aplicada na formação circense.

A questão da tipologia das personagens já demonstra um direcionamento e especialização dos artistas estudados, pois cada tipo recebe uma qualidade de aparatos que potencializará a performance do ator na cena: efeitos, pausas, triangulação, o dimensionamento da fé cênica, a empatia a ser criada pelo par romântico, o ódio a ser construído pelo vilão e, principalmente, a consciência de ser um coadjuvante com seus tempos 
de espera precisos em relação à interpretação do personagem principal. Esse entendimento é o mesmo visto na dupla cômica dos palhaços e que recebe o nome de "escada".

A mecânica de encenação do circo-teatro dialoga diretamente com a dramaturgia das entradas e esquetes circenses encenadas pela dupla cômica de palhaços. Os entrevistados se apoiaram nas técnicas da dupla cômica principalmente no que diz respeito à polaridade do racional e do intuitivo, ou seja, o Branco e o Augusto, respectivamente.

Essa convenção é descrita por Roger e Tabajara como ponto de partida da estruturação da dramaturgia do palhaço e está embasada na tradição e transmissão oral de palhaços de várias épocas e locais. Imagino que a polaridade da dupla cômica tenha nascido no exato momento em que alguém ironizou outrem em posição de maior poder; essa ironia começou no pensamento e tornou-se cena, e a partir daí o "reprimido" conquistou uma horizontalidade que norteou a dramaturgia de todos os palhaços da humanidade.

Neste texto, delinearei a relação entre o circo-teatro e a dramaturgia do palhaço por meio do olhar analítico de Carlos Alberto Soffredini, com quem absorvi práticas a respeito da estética teatral em questão que influenciou meus trabalhos com linguagem clownesca.

Carlos Alberto Soffredini se destacou no panorama teatral brasileiro com seus textos bem elaborados e com profundas pesquisas de campo. Suas direções artísticas seguiram vários caminhos, mas o calcado na estética popular nos deixou referenciais importantes no que diz respeito à estruturação de linguagem. $\mathrm{O}$ artista elaborou procedimentos pedagógicos para formação de atores e atrizes que pudessem realizar a estética do circo-teatro em suas encenações teatrais.

A pesquisa do artista é aqui disponibilizada por meio de dois suportes: o prático, no qual descrevo algumas experiências nos ensaios da peça "Minha Nossa" com o Núcleo de Estética Teatral Popular (Núcleo ESTEP); e o teórico, com recortes do seu texto "De um trabalhador sobre seu trabalho" (1980), que demonstra a riqueza do circo-teatro brasileiro e de como ele se imbrica na formação do palhaço da matriz circense.

Outro autor que fornece subsídios teóricos para demonstrar a importância da estrutura teatral do palhaço é Mario Bolognesi, em seu livro "O palhaço" (2003), do qual enfoco as questões ligadas à dupla cômica, questões estas que são reforçadas nas entrevistas com Avanzi e Tabajara.

A dupla Augusto e Clown Branco, então, veio a solidificar as máscaras cômicas da sociedade de classes. O branco seria a voz da ordem e o Augusto, o marginal que não se encaixa no progresso, na máquina e no macacão do operário industrial (BOLOGNESI, 2003, p.78). 


\begin{abstract}
Uma entrada circense é um esquete curto, levado à cena pelos palhaços, com duração aproximada de 15 ou 20 minutos, podendo estender-se a partir da interação com a plateia, em um jogo improvisado. Desconhece-se a origem do termo "entrada". Ele pode se referir às paradas circenses, efetuadas como formas de divulgação do espetáculo, quando os artistas exibiam uma síntese de seus talentos na porta de entrada dos circos franceses, esperando que o público adquirisse o ingresso e entrasse no recinto. Outra provável origem do termo diz respeito à brevidade paródica das intervenções dos clowns nos espetáculos equestres. Nesse caso, contudo, o termo equivalente, "reprise", seria o mais adequado, pois a atração circense estaria sendo reprisada às avessas. A participação dos palhaços, assim, seria uma espécie de intervalo cômico entre duas atrações sérias (BOLOGNESI, 2003, p. 103).
\end{abstract}

Em 1978, Roger Avanzi iniciou trabalho como professor de palhaço e bicicleta na Academia Piolin de Artes Circenses (APAC) e afirmou que a melhor didática para ensinar a arte do palhaço foi a de ensaios de entradas e esquetes, pois conseguia abranger os conceitos básicos e necessários a um palhaço.

Essa escolha pedagógica de Roger é muito reveladora para nosso estudo, pois por meio dela é possível perceber que a consciência teatral de um palhaço é a base de sua criação e que as técnicas corporais (mímica e acrobacia) e a forma (maquiagem e vestimenta) que escolhe para manifestar seu discurso vêm como suporte de representação.

Por meio dos esquetes e entradas, o palhaço define sua linguagem: corporal, verbal ou musical, e também define o cerne de seu palhaço (Branco ou Augusto); enfim, ele define a maneira como vai jogar.

É certo afirmar que Roger tinha várias habilidades antes de ser palhaço: cavaleiro, ciclista, trapezista, ator e músico. Foi Tony de Soirèe por causa dessas habilidades e veio a ser o palhaço Picolino 2, para substituir o pai adoentado. Muitos ensaios foram desenvolvidos com o ensaiador do Circo Nerino (que também seria seu clown) para essa substituição; apesar de toda essa familiaridade com os artistas envolvidos na mudança no circo de sua família, Avanzi narrou o nervosismo desta estreia no próprio circo.

Em entrevista com Val de Carvalho, captei a exigência que Roger aplicava nos ensaios e repasses das entradas. Ela também narra dificuldade de Carvalho em absorver o entendimento dos tempos cênicos das falas e das ações, fatores que comprometiam totalmente o desenvolvimento e arremate da encenação. Val comenta que o que mais atrapalhava era sua formação como atriz, que se refletia numa demasiada valori- 
zação das falas ou a necessidade de esboçar justificativas psicológicas para algumas ações. Picolino dizia que ela "pensava demais" para executar as cenas.

Carlos Alberto Soffredini nos fornecerá uma análise mais aprofundada sobre a questão "pensar demais", mas adianto que entre seus ensinamentos sobre estética e linguagem popular destacava que "um ator em cena não pensa, ele atua". Para alcançar esse conceito, sempre enfatizava que uma preparação corporal corroborava esse entendimento, fato que comprovamos após vários trabalhos que verticalizaram essa ideia.

Nemes Bastos realizou uma entrevista com Fernando Sampaio, ator da Cia. La Mínima que iniciou seu aprendizado como palhaço com Roger Avanzi e revela um pouco de como se desenvolviam as aulas:

Na verdade, os meus primeiros encontros com o Picolino foram aulas de monociclismo. Quando eu fiz aquela oficina de palhaço com a Val de Carvalho em 1988 ela sugeriu que eu fosse ao Circo Escola Picadeiro fazer aula com o Roger Avanzi [...]. Era uma aula longa, com duas horas de duração. Então ele me ensinava um esquete num dia, me falava sobre Abelha, Abelhinha, sobre alguma entrada... Isso só eu e ele. Ele dizia "hoje eu vou te falar sobre um esquete". Ele falava, eu escutava e depois, durante uma hora e meia, eu pegava o monociclo e ficava andando com ele. Fiz monociclo, bicicleta, monociclo alto, monociclo de dois metros, de quatro metros... Na verdade, para mim era importante estar perto dele. Eu tinha, ou melhor, tenho uma admiração muito grande pelo Roger. [...] Eu era aquele sujeito que todo dia ia na aula do Roger, eu me esforçava para ir. Queria agradá-lo, tinha que agradá-lo de alguma forma. Eu tinha que estar perto dele, mostrar interesse... só assim eu iria conquistá-lo. Eu queria conquistar o Roger. Eu queria ser o Roger (BASTOS, 2013, p. 239).

A narração de Sampaio enfatiza a importância dos ensaios de esquetes e entradas, tanto para o professor, que elabora seu programa de aulas, quanto para o aluno, que se confronta com uma metodologia oral. O fato sobre a potência dos ensaios denota que a transmissão oral de conhecimentos dramatúrgicos e de atuação se operacionalizavam por meio da literatura oral, que Roger acessava em sua memória. Estar perto de Avanzi era estar à disposição de ensinamentos que eram associados ao momento do aprendizado e à atenção do aluno.

Outro aspecto de aprendizado do contato de Sampaio com Roger, que corrobora a importância das entradas e esquetes na formação do palhaço na matriz circense, é o de assisti-lo atuando como Picolino. É em ação que se pode comprovar os efeitos e a potência da encenação do palhaço. Outro trecho da entrevista ilustra a afirmação acima: 
Uma vez eu o vi e fiquei impressionado. Era ele e o Pinguim [José Pereira dos Santos], a dupla dele naquele momento. O Pinguim era um anãozinho. Um gênio também, um ótimo palhaço! Quando eu os vi juntos foi sensacional. Eles faziam um número acrobático numa escada. O Roger subia numa dessas escadas de duas pernas de apoio, o Pinguim subia também, eles desciam para pegar uma lata e subiam novamente, o Roger de um lado, o Pinguim do outro. Eles simulavam uma briga em cima da escada e o Pinguim entrava dentro da camisa do Roger - o Roger usava umas camisas muito largas - ficava meio preso na calça, o Roger descia da escada e o Pinguim saía pela barra da calça do Roger. Antes de sair, eles tiravam uma foto. Imagine a cena: o rosto do Pinguim aparecia na barra da calça do Roger! O Pinguim tinha uma cara muito boa, era engraçado. Tinha um trejeito no corpo, os braços pequenininhos, como toquinhos. Era sensacional (BASTOS, 2013, p. 240).

Lilian dirige uma pergunta a Sampaio que diz respeito à imitação como ponto de partida na construção de um palhaço. Tal questão nos faz refletir sobre um aprendizado que se dá ao assistir palhaços muito experientes, os quais encenam suas entradas com muita atitude e desenvoltura, demonstrando uma apropriação completa de técnicas e de expedientes dramatúrgicos, estas performances servem como forte referência para iniciantes.

A resposta de Sampaio nos revela duas informações importantes: a primeira sobre a inspiração que esses experientes palhaços nos causam, e a segunda, um posicionamento ético sobre copiar como ponto de partida e de chegada do processo de aprendizado.

Não passava na minha cabeça imitá-lo, como eu já vi pessoas reproduzindo os mesmos trejeitos de outro palhaço... Você pode fazer a mesma entrada, mas algumas pessoas usam as mesmas piadas, fazem os mesmos trejeitos. Eu ainda não era palhaço. O Roger para mim era fonte de inspiração, eu queria ficar com ele, nem que eu só fizesse aula de monociclo. Quando ele não dava aula de palhaço, só de bicicleta, para mim não tinha problema nenhum. Eu queria estar ao lado dele. Era paixão, eu era muito apaixonado pelo Roger (BASTOS, 2013, p. 240).

Arlindo Pimenta não foi professor de palhaços, mas sua trajetória como aprendiz revela como os procedimentos teatrais agregaram valores ao seu desempenho como palhaço: seu caminho que se inicia como "porta voz" da divulgação nas ruas, passa pelo trabalho como ator de circo-teatro, mestre de pista, depois como clown e, finalmente, como palhaço de entradas - demonstra que essas fases de formação são, além de um processo vivo, seguimentos de uma formação bastante concreta.

A trajetória de Arlindo Pimenta permite realizar um recorte a respeito da dupla cômica, pois ele foi se conscientizando e praticando essa polaridade durante muitos anos. A estrutura das 
famílias circenses itinerantes brasileiras já comportava a dupla cômica que, por conseguinte, se utilizava das entradas e reprises para expor os personagens nos espetáculos. Todos os palhaços oriundos da matriz circense brasileira obedecem a esse esquema como ponto de partida para o ensino e prática dos palhaços.

Na entrevista de Tabajara Pimenta, temos a informação de que Arlindo, mesmo sendo um clown experiente, teve dificuldades quando ensaiava para ser palhaço e que, quando entrou em cena, realizou uma mudança radical na expressão vocal, pois fazia uma voz esganiçada e aguda, baseada no antigo palhaço e, no picadeiro, alterou para um tom mais grave e com sotaque italiano. Em relação ao roteiro ensaiado não houve mudança alguma, além daquelas em relação ao público e às triangulações que estabelecem o jogo no momento da representação. Arlindo Pimenta também realizou seus ensaios diretamente com seu futuro clown, que também era o ensaiador do circo, caso semelhante ao ocorrido com Roger Avanzi em sua transição para o palhaço de entradas. É interessante recortar e analisar a coincidência sobre os ensaiadores também serem os clowns dos futuros palhaços, e sobre o nervosismo de estreia, apesar de toda a familiaridade com o ambiente e os artistas da dupla cômica. Enfatiza-se mais ainda a importância que o palhaço tinha na estrutura do espetáculo circense e de como a criação e execução das entradas recebiam uma atenção especial para a criação.

Destaco uma colocação de Mario Bolognesi sobre a evolução do termo clown no circo e como foi se configurando a dupla cômica:

\begin{abstract}
No universo circense o "clown" é o artista cômico que participa de cenas curtas e explora uma característica de excêntrica tolice em suas ações. Até meados do século XIX, no circo, o "clown" tinha uma participação exclusivamente parodística das atrações circenses e o termo, então, designava todos os artistas que se dedicavam à satirização do próprio circo. Posteriormente, esse termo passou a designar um tipo específico de personagem cômica, também chamado de "Clown" Branco, por conta de seu rosto "enfarinhado", que tem no outro palhaço, o Augusto, o seu contrário. O plural "clowns" é usado para designar a dupla cômica. No Brasil, no meio circense, é comum ouvir-se o termo "crom" em referência àquele palhaço que tem a função de "partner", ou de palhaço secundário (BOLOGNESI, 2003, p. 62).
\end{abstract}

A dupla cômica é de suma importância para o desenvolvimento da ação dramática nas entradas, e identificar as possibilidades do jogo e dos conflitos confere ao público uma atitude de complementação dramatúrgica, ou seja, a plateia se torna ativa durante a encenação, pois imagina, intui, sabe as possibilidades de cada personagem na dupla; o público fica focado 
no desenrolar da ação dramática, seja ela transmitida verbalmente, por mímica, por aparelhos ou musicalmente.

Nas entrevistas com os outros professores foi registrado que a elaboração de esquetes é ferramenta essencial para o desenvolvimento de cada aluno/palhaço, pois ele se confronta com questões apontadas até aqui sobre a dupla cômica. Quando estamos em jogo entre palhaços, o entendimento sobre quem é quem na relação torna-se uma necessidade-base para um desenvolvimento eficaz da encenação, além do entendimento sobre dramaturgia e a ordenação das ações na cena.

Mesmo quando o aluno/palhaço opta por realizar solos, ele aplica o conceito da dupla cômica por meio de conflitos com objetos, com o público, com situações pré-colocadas. Um bom exemplo é um tipo de ação dramática que gosto de chamar de "Anti Número", no qual o palhaço anuncia que fará algo, mas a tentativa é que se torna o foco da graça, a complicação é o número real. Muitos palhaços, tanto da matriz francesa quanto da circense, desenvolveram esquetes e entradas com esse mote; chamo a atenção, particularmente, para a concentração do conceito da dupla cômica.

Um palhaço em jogo com outro palhaço pode oscilar tanto na postura de um Branco quanto na de um Augusto, dependendo da proposta de cena, e isso pode acontecer em números solo também. Nos exemplos com Roger e Arlindo esse fator não me foi apontado: o circo nos quais trabalharam adotaram destacar a dupla e apresentar entradas que se apoiavam nessa estrutura, mesmo que a postura do Branco viesse no Mestre de Pista, ou como outra figura identificável pelo público: um policial ou a esposa, por exemplo.

Tabajara Pimenta exemplificou essa dramaturgia apoiada na dupla cômica numa entrada em que participava como Branco: o mestre de pista anunciava a presença do gerente do circo no picadeiro, que agradecia a presença da seleta plateia; depois ele ia para a cortina de fundo e ficava conversando com o mestre de pista. Neste ínterim, entrava um palhaço com uma escada e pedia a ajuda do gerente do circo para segurá-la em seu número. O palhaço vinha com vários copos, jarro e uma bandeja, enchia os copos com líquido colorido e subia a escada. O número consistia em equilibrar, por meio de uma vara, a bandeja com os copos cheios de líquido enquanto subia a escada. Tabajara era encharcado pois ficava bem embaixo da ação; no fim tudo estava amarrado por fios e o palhaço saía correndo do gerente. Nas palavras de Pimenta: "O público vinha abaixo quando alguém de smoking era humilhado, fazíamos assim para que o mestre de pista ficasse a postos para anunciar o próximo número... funcionava. Ninguém ia rir se fosse com um "barreira" (funcionário que ajuda os artistas a colocarem os 
aparelhos de seus números, um ajudante de picadeiro). A graça era ser com uma autoridade, o patrão”.

Outra observação de Mario Bolognesi aponta mudanças na forma do Branco ou Clown nos circos atuais, mas sua função dramatúrgica permanece:

\begin{abstract}
A pesquisa realizada nos circos brasileiros não encontrou nenhum Clown Branco. As suas funções foram absorvidas pelo apresentador (Mestre de Pista) ou por um segundo palhaço, também ele Augusto, chamado de "escada" ou "crom". Os palhaços brasileiros da atualidade não têm mais as características externas dos primitivos clowns, embora tenham absorvido muitas das proezas por eles desenvolvidas. O repertório, conhecido e acumulado, foi incorporado pelo tipo Augusto. Há, no circo brasileiro da atualidade, um predomínio do Augusto. As atribuições do Clown Branco foram incorporadas por essa figura exemplar. Mantém-se, contudo, a permanência em cena de uma dupla de palhaços, ao menos (BOLOGNESI, 2003, p. 91).
\end{abstract}

Nos cursos que promovi sempre considerei a criação de esquetes uma ação essencial, como também enfatizei a importância do entendimento da dupla cômica, tanto como ferramenta de jogo formativo como experimento dramatúrgico. Na matriz francesa de formação de palhaços, mais especificamente com Gaulier, utiliza-se o termo protagonista da cena; o outro assumiria o papel de "escada", termo também usado no circo. O "escada" permeia a estética popular mais verticalmente em personagens e palhaços que se apoiam na verbalidade, na comédia ligeira de respostas rápidas e precisas. $\mathrm{O}$ "escada" atua dramaturgicamente como um Branco.

É difícil estruturar duplas cômicas quando se desenvolve oficinas curtas, ou mesmo longas. A razão maior é que os alunos preferem dedicar os ensaios a serem mais ecléticos e jogarem com o palhaço que tiverem disponível para as cenas; existe a questão autoral na qual o aluno/palhaço cria seu esquete com essa estrutura de oscilação.

A citação de Bolognesi corrobora essa tendência dos palhaços de se apresentarem ao público numa forma menos fechada como a dupla evidenciada na forma. Na minha opinião, o público perde a beleza com que os clowns faziam questão de se mostrar, visto que o sublime era evidenciado em grande esplendor. No entanto, essa adaptação traz vantagens práticas que se revelam, principalmente, na dramaturgia e encenação, pois os palhaços podem combinar esquetes em que o jogo de mudanças do papel de Branco e de Augusto possa ser explorado para gerar o riso.

Como foi delineado, a teatralidade desenvolvida pelos palhaços se expande por meio de vários aspectos técnicos: dra- 
maturgia, forma, materialidades, corpo, voz, música e contato com o público. Muitos debruçaram-se sobre esses aspectos para transportar essa estética para outras linguagens e expressões. Mais à frente serão expostas experiências práticas que expõem a potência desta teatralidade.

\section{Dramaturgia e encenação circense}

O espetáculo do circo-teatro tem uma finalidade imediata: ele não é feito para ser avaliado pelos entendidos ou pelos críticos especializados, nem para ser comentado nas mesas dos bares da moda, nem para ir figurar nos anais da história do espetáculo. Não: ele é feito para agradar o público, para que este volte no dia seguinte e compre seu ingresso na bilheteria para possibilitar ao artista a compra de comida no dia seguinte (SOFFREDINI, 1980, p. 4).

Carlos Alberto Soffredini realizou uma pesquisa bastante consistente sobre a estrutura do espetáculo circense, mais especificamente em relação ao circo-teatro e seus expedientes. Suas observações foram aplicadas ao desenvolvimento de sua dramaturgia e na formação de atores, o que culminou com a montagem do espetáculo "A Vida do Grande D. Quixote de La Mancha e do Gordo Sancho Pança", em 1976, com o Grupo Mambembe. Esse trabalho orientou e propiciou a estruturação de uma linguagem e estética teatral de base popular que veio a direcionar trabalhos como "Vem buscar-me que ainda sou teu", "Minha Nossa" e "Na Carreira do Divino", entre muitos outros que realizou com grupos nos quais desenvolveu pesquisas de estética popular e formação de atores.

A importância do olhar deste artista em relação ao circo torna-se vital para a análise da formação da matriz circense, objeto de pesquisa deste trabalho, pelo motivo de que Soffredini estruturou uma linguagem teatral totalmente calcada na matriz em questão. A dramaturgia criada por Soffredini tem fortes laços com a dramaturgia encenada nos circos-teatros; a familiaridade é encontrada na construção das personagens e na ação dramática, características que foram absorvidas por Roger Avanzi e Arlindo Pimenta nos espetáculos de circo-teatro que encenaram. Essa vivência incorporou-se em seus trabalhos como palhaços, tornando-se uma estrutura básica de criação e encenação dos esquetes e entradas.

Os procedimentos circenses revelados nas montagens teatrais de Soffredini foram observados e analisados por ele nos trabalhos de atores e palhaços circenses. É possível constatar em sua dramaturgia e encenação uma relação direta com fundamentos utilizados pelos palhaços pesquisados neste trabalho. A análise e práticas de formação de atores de Soffredini, com 
o uso na construção de repertório dos esquetes e entradas dos palhaços, é fator essencial na formação de qualquer palhaço, pois um palhaço da matriz circense não se estabelece teatralmente sem essas noções dramatúrgicas.

Outra contribuição de Soffredini a este trabalho diz respeito às técnicas de interpretação e de construção de cenas: as concepções artísticas das peças que escreveu e dirigiu o impeliram a desenvolver uma pedagogia de formação de atores que não tiveram a vivência circense, mas tiveram que incorporar essas mesmas técnicas de interpretação desta matriz para que sua dramaturgia se estabelecesse em cena.

Trabalhei como um desses atores que não tinham os conhecimentos almejados por Soffredini, vivenciei suas didáticas que almejava esse ator popular, de corpo expandido, que se impregnasse com técnicas como a mímica, triangulação, Commedia dell'arte, personagens tipos e expedientes épicos - procedimentos muito comuns ao palhaço.

Nas próximas linhas, farei uma descrição do contato que tive com a pedagogia de repasse da linguagem e estética popular difundida por Soffredini, por acreditar que sua metodologia artística de direcionar a montagem de um espetáculo e a formação dos atores envolvidos no processo tenha um escopo semelhante ao de uma montagem de circo-teatro e de reprises de palhaços, no que diz respeito à disciplina de ensaios, práticas técnicas (treinamentos) e à busca de agradar ao público.

É importante destacar que o processo de formação do palhaço circense oferece um sistema calcado na experiência cotidiana com o público, com a necessidade material e artística de fazer o espetáculo dia após dia, na renovação e adaptação dos aspectos estéticos e culturais de cada número e o comprometimento com aspectos tradicionais, que são transmitidos oralmente geração após geração. Esses fatores estão imbricados na maneira de fazer teatro de Soffredini e na minha formação como artista de teatro e como palhaço.

As descrições que se seguem explicitam a relação direta dos itens descritos acima, advindos da matriz circense, que foram absorvidos por Soffredini e que, posteriormente, tornaram-se a base de minha formação como palhaço.

Soffredini estruturou sua pesquisa nos anos 1970, em visitas contínuas a circos, e depois sistematizou sua estética com o Grupo Mambembe. A partir de então, viabilizou o compartilhamento de sua pesquisa em outras montagens, que propiciaram um amadurecimento vindo a se transformar em didáticas que pude experienciar, a partir de uma oficina de interpretação realizada na Fundação das Artes de São Caetano do Sul (FUNDART) em março de 1985. Foi mais um encontro importante para estruturação do entendimento da estética popular no teatro e 
do palhaço circense que viria a se tornar minha referência estética em montagens da "Cia. Picnic de teatro"2.

Na oficina citada, trabalhamos vários expedientes pesquisados e otimizados por Soffredini; seus fundamentos foram expostos por meio de apreciações de cenas exercícios, e focavam os aspectos da linguagem popular: a farsa; a triangulação; a estruturação de um estereótipo convincente; uma expressão corporal expandida; o estudo de tipos e a dramaturgia.

O tempo de duração da oficina foi curto (duas semanas) foi um encontro, que somado à oficina de Clown de Francesco Zigrino da qual participei duas semanas antes, promoveu uma sequência de reflexões em relação ao meu trabalho no teatro amador. Percebi que fazia teatro para um público popular, com temática popular e trabalhista (pois meus grupos eram de sindicatos), mas a estética de nossas peças de palco se apoiava numa linguagem realista, com quarta parede. Por outro lado, realizava peças na rua que vieram a ganhar, a partir dessa reflexão, uma potencialização na direção de uma maior busca de contato direto com o público, fator comum aos palhaços da matriz circense.

Ainda em maio de 1985 fui convidado por Soffredini, juntamente com outros participantes da oficina da Fundação das Artes de São Caetano do Sul, a fundarmos o Núcleo de Estética Teatral Popular (Núcleo ESTEP) e a montarmos a peça "Minha Nossa", de autoria do próprio Soffredini, que também dirigia o espetáculo.

No mesmo ano continuamos a trabalhar todas as noites na Fundação das Artes que, na época, só oferecia cursos livres. Tornamo-nos um curso à parte, pois Soffredini trouxe profissionais para nos instrumentalizar: Ilder Miranda Costa, para nos dar uma formação musical de canto; Paulo Yutaka, para nos ensinar mímica, juntamente com Eduardo Coutinho; Eudosia Acuña, para nos dar aulas de expressão vocal; Fernando Neves, para expressão corporal, e Walmir Santos, para direção musical.

Foram sete meses de intenso trabalho artístico, que se dividia em formação e encenação. Foi meu primeiro contato com um programa de formação de atores e atrizes que me fez entender a importância de uma formação técnica direcionada às necessidades estéticas de um espetáculo específico.

Estava familiarizado em fazer pesquisa de mesa e de campo, ação que se repetiu no Núcleo ESTEP. O que foi novo para mim foram as questões ligadas à análise dramatúrgica, realizadas por Soffredini com seu próprio texto, fator muito enriquecedor. Em relação ao processo de encenação e produção de "Minha Nossa", as questões que criaram mais dialética em relação a minha trajetória até então foram:

-Devemos ter obediência cega ao diretor?

-Não existe limite para dedicação à pesquisa e estudos de metodologias?
2.

A Cia Picnic de Teatro surgiu em1992 com o espetáculo "Um dia de Pic e Nic", que teve concepção geral de Chiquinho Cabrera e Edu Silva e foi calcado nos aprendizados obtidos no Núcleo ESTEP, dirigido por Carlos Alberto Soffredini, que foram somados aos métodos de formação de clown de Francesco Zigrino. O espetáculo continua em cartaz e realizou mais de mil apresentações. Outros espetáculos montados pela companhia também se utilizaram da linguagem clownesca: "Avoar", de Vladmir Capella, "Estação Pic Pan Pum", "Conto de Encontro". "Chapeuzinho Vermelho" e "À moda da Casa”, de Daniele Pimenta e Edu Silva. 
- Como escolher as técnicas adequadas à estética pesquisada?

-Quanto tempo mais era necessário para estruturação de uma linguagem?

Considero as experiências de se apresentar em temporadas periódicas, num só teatro, e depois partir para apresentações mambembes, como parte do aprendizado do ofício de ator. Estar em contato com públicos de culturas diferenciadas trouxe enriquecimento para as técnicas absorvidas e treinadas pelo Núcleo ESTEP, que "engatilhou" outra montagem dentro da mesma estética: "Na Carreira do Divino".

Soffredini nos instrumentalizou com técnicas específicas que seriam meios para alcançar uma estética que correspondesse à poética contida em seus textos. A dramaturgia de Soffredini contém forte vínculo com o teatro popular; desta forma, solicita certos entendimentos de circo-teatro e suas bases: tipologia das personagens; triangulação; ponte; escada; efeito; revelação; estereótipo ( "[...] não existe o mau estereótipo. Existe, sim, o mau ator"); ritmo de encenação e visualidades. Os pontos citados estão muito bem explicados em seu texto "De um trabalhador sobre seu trabalho" (SOFFREDINI, 1980).

Foi uma experiência pedagógica muito rica, pois esses expedientes populares que foram captados e absorvidos em picadeiros e palcos de circo por Sofredinni passaram por um estudo acadêmico e, posteriormente, contaminaram a dramaturgia e a forma de dirigir de Soffredini, que se motivou a construir essa pedagogia para formação de atores e atrizes advindos do teatro amador de cunho realista.

Dentre todo o aprendizado de teatralidades que absorvi no Núcleo ESTEP, cinco focos impregnaram meu modo de entender teatro e, depois, de entender as necessidades de formação do palhaço: mímica, triangulação, efeito, dramaturgia e forma.

A preparação corporal do elenco que montaria a primeira peça do Núcleo ESTEP, "Minha Nossa", foi baseada na mímica e na consciência e "limpeza" que a técnica imprime nos artistas que a praticam. Paulo Yutaka ${ }^{3}$ e Eduardo Coutinho ${ }^{4}$ contribuíram com a formação dos atores e atrizes também no que se refere a estruturar uma dramaturgia do corpo, pois dirigiram composições de cenas totalmente calcadas na técnica da mímica e que davam um caráter lúdico que expunha a teatralidade pesquisada por Soffredini.

Praticávamos os elementos básicos da mímica: peso, forma e espasmo, para, posteriormente, imprimi-los em cenas que exigissem uma complementação por parte do público de elementos cenográficos. Assim, o texto de Soffredini que falasse de uma cozinha de forma narrativa, teria a construção de elementos dessa cozinha realizada por meio da mímica. Essa
3.

Fundador, em 1983, do Grupo Ponkã juntamente com Celso Saiki, Carlos Barreto, Ana Lúcia Cavalieri, Milton Tanaka, Hector Gonzales, Graciella de Leonnardis e o Galizia. Montaram os espetáculos Aponkãlipse, O Próximo Capítulo, o Ballet da Informática e O Primeiro Capítulo. Em fins de 1985 montaram Pássaro do Poente, um texto de Carlos Alberto Soffredini, sob a direção de Marcio Aurélio. O grupo era composto por filhos e netos de imigrantes orientais e ocidentais e o Ponkã, tal como a fruta mestiça da mexerica e da laranja, buscou articular uma síntese teatral que expressasse essa condição.

4.

Ator-mímico, estudou em Paris com Ella Jaroszevski e o Théâtre du Moviment (1984) e, no Brasil, com Sotero (1978), Denise Stoklos (1982) e David Glass (1988). Mestre, pesquisando a Mímica como técnica de aprimoramento da representação teatral e Doutor em Artes, pesquisando o texto corporal na cena, ambos pela ECA-USP. É professor do Departamento de Artes Cênicas da Escola de Comunicações e Artes (ECA) da Universidade de São Paulo (USP) e vice-coordenador do Centro de Pesquisa em Experimentação Cênica do Ator (CEPECA). 
linguagem iria se manifestar futuramente num espetáculo escrito e encenado por mim, que seria calcado também na figura do palhaço: "Um dia de Pic e Nic".

A triangulação foi uma das técnicas mais importantes que absorvi e que considero essencial à formação do palhaço porque, simplesmente, coloca o público como eixo de toda a encenação, como um comparsa que potencializa todas as reações do ator e, no nosso caso, do palhaço.

A triangulação é uma técnica de comunicação popular muito utilizada pelos atores das feiras e praças, por encenações calcadas em máscaras e nas que utilizam bonecos. O palhaço de circo triangula o tempo todo e "joga" para o público suas ideias, sentimentos, suas dúvidas, suas descobertas, seus medos e suas intenções. Como toda técnica, deve se tornar orgânica para enfatizar a ação dramática e não o virtuosismo da própria técnica. Nas palavras de Soffredini, a técnica é descrita assim:

Nada de Stanislaviski, nada de quarta parede. O ator se entrega sim, ele se envolve sim, mas em nenhum momento ele se esquece que está num palco, nem por um segundo ele ignora o público. Pelo contrário: na maior parte das vezes ele "contracena" com o público, estabelecendo o que nós chamamos de "triângulo". Assim: dois atores em cena; UM deve fazer uma pergunta para o OUTRO; UM faz a pergunta para o público e não diretamente para o OUTRO (nada de relação olho-no-olho, portanto); e o OUTRO responde também através do público. Parece uma coisa simples, mas essa forma de contracenar sempre "através" do público põe este último sempre no centro da representação. Outra forma de estabelecer o "triângulo": as ações e reações de um ator (personagem) estão sempre abertas para o público (não há psicologismos e por isso não há jogos escondidos). Se um ator, por exemplo, reage ao que um outro ator está dizendo ele "diz" (mesmo sem palavras) a sua reação diretamente para o público. Dessa forma pode-se também, por exemplo, valorizar muito cada nuança da intenção de um ator que fala, através da reação que ele causa no seu interlocutor.

Mas vamos falar mais sobre o processo do Triângulo que é, observamos, a base de qualquer tipo de apresentação popular.

O público é o vértice de maior peso no triângulo. É o CÚMPLICE na representação. É o CENTRO dela. É para ele que se CONTA a história, portanto ele é o dono dessa história. Muitas vezes ele conhece dados dela que ou um ou os outros dois vértices do triângulo (os atores) desconhecem. Ele conhece o caráter e a intenção de cada personagem, uma vez que cada ator, ao entrar em cena, deve ter como meta REVELAR o seu personagem, a intenção dele e, é claro, a sua ação dentro da ação (história). A partir dessa CUMPLICIDADE com o público, dessa CENTRALIZAÇÃO nele, dessa DOAÇÃO a ele da ação (história, representação) é que se estabelece a base do jogo teatral. Os gregos já sabiam disso. $\mathrm{E}$ as velhas peças românticas abriam margem para esse jogo através do A PARTE, que, em última análise, é a forma tosca a partir da qual, elaborando, nós chegamos ao processo do TRIÂNGULO (SOFFREDINI, 1980, p. 5). 
Com a técnica da triangulação, aplica-se um caráter matemático à encenação, deixando o público sempre ativo no momento teatral e, com Soffredini, exercitamos e depois aplicamos triangulações que envolviam todo o elenco numa única reação, que se voltava para o público: um susto diante de uma revelação, uma expressão coletiva de alívio seguida da fala contraditória de uma personagem etc. Muitas vezes Soffredini utilizava essas reações trianguladas em coro, em massa, e salientava que a triangulação só é eficaz se os atores olharem de verdade para o público e captarem a reação deste, para poderem devolver para o ator com quem contracenamos com essa verdade; assim, 0 fluxo do jogo ganhava uma força cênica compatível com a linguagem com a qual trabalhávamos.

A lógica de se juntar a triangulação à mímica era visível na formação da linguagem, à qual também se agregava o conceito de se montar um bom estereótipo. O resultado era um corpo expandido, todo focado para o público, inclusive o olhar. Mais tarde eu entendi que a técnica de triangulação havia me conferido um expediente de me comunicar muito diretamente com esse público, a ponto de montar um mapa mental da localização de certas figuras da plateia que poderiam dinamizar a encenação de uma peça com comentários diretos e específicos: a senhora que ri alto, a criança que comenta algumas cenas, o senhor carrancudo, pessoas que estariam disponíveis para brincadeiras e chistes.

Acredito que esse expediente de "escanear" o público é ferramenta vital ao palhaço, que, sem isso, corre o risco de fazer uma viagem solitária em seu espaço de encenação.

Em relação ao quesito "efeito", Soffredini acreditava que era uma consciência essencial à linguagem e à formação de ator que a estética pesquisada exigia. Uma das questões era buscar essa consciência no ator para que se tornasse uma atitude cênica que se revelasse no corpo, na triangulação e no comentário desse ator. Nas palavras do próprio Soffredini:

E eis-me aqui novamente tocando num ponto delicadíssimo no dito Teatro Moderno e simplesmente abominado pelos filhos de Stanislaviski: o EFEITO. Efeito cheira à forma. E nesse ponto seria bom que a gente chegasse logo a um acordo: NÓs CULTIVAMOS A FORMA. Os antigos atores conheciam e aprimoravam uma série de EFEITOS. Eles sabiam a forma de dizer melhor uma piada, o valor exato de uma pausa, a maneira de se colocar em cena dependendo do clima a ser criado ou do caráter a ser revelado. Não é por acaso que o CircoTeatro ainda conserva uma fuga central no cenário. Não se trata dessas atuais convenções pobres, tais como: "a fuga da esquerda leva ao quarto, a do centro à cozinha, a da direita leva à rua...” Não. Trata-se de uma consciência exata do valor (efeito) da entrada ou saída de um ator de cena. Cada personagem que entra em cena, se o ator souber entrar, só pode levar a peteca pra cima. Cada perso- 
nagem que sai, se o ator souber sair, deixará a peteca em cima. Se um personagem tem caráter positivo, se ele "chega", entrará pela fuga do meio: como num passe de mágica a figura aparecerá no meio da cena. Da mesma forma, se um personagem tem caráter dissimulado, se sua ação é sorrateira, ele entra ou sai pelas laterais. Parece um processo ingênuo, mas o EFEITO é matemático. Sabe-se que os "vilões" dos velhos dramas não só entravam em cena pelas laterais como cobrindo parte do rosto (do nariz pra baixo) com uma capa negra (SOFFREDINI, 1980, p. 6).

Soffredini aplicou o conceito diretamente na cena, por meio da direção de atores. O procedimento da repetição mecânica que, em muitas ocasiões, nos levava à exaustão, promoveu a absorção do conceito. A atitude do ator em realizar "efeitos" foi motivada com essas repetições das ações das cenas, ensaiadas com esse objetivo, e foram aliadas às técnicas de triangulação como disparador do enfoque do público, mais as técnicas da mímica.

Em relação à dramaturgia, o aprendizado foi intenso, pois Soffredini, além de ser um dramaturgo muito competente, escrevia para a linguagem pesquisada e, ao fazermos as leituras de mesa, os procedimentos dramatúrgicos nos eram revelados e já ensaiados. Recebemos os conhecimentos sobre o uso do tipo para composição das personagens; como ele pesquisou esses tipos in loco quando escrevia "Minha Nossa"; como construiu no texto as narrativas épicas; como aplicou os gêneros épico, lírico e dramático e o objetivo que queria alcançar com suas escolhas. É importante citar que Soffredini não escreveu imaginando ou prevendo sua direção, pois dirigiu seus textos no Núcleo ESTEP depois que outras companhias já os haviam montado.

O entendimento do quesito dramaturgia é vital ao palhaço, pois, mesmo que realize improvisações decorrentes do jogo com o público, ele segue uma linha de ação dramática e, sem esse entendimento, terá sérias dificuldades em aplicar a triangulação e o efeito. No Núcleo ESTEP tivemos várias aulas sobre dramaturgia, nas quais Soffredini explicitava seu método de escrever, como, por exemplo: escrevia as cenas de forma independente, sem preocupar-se em sequenciá-las; dava títulos para as cenas para lembrar qual ação dramática havia desenvolvido nelas; pregava as cenas na parede e depois fazia as ligações, reordenando-as, até o fechamento da peça.

Esse raciocínio é muito revelador para um ator que buscará a improvisação em seus trabalhos, pois demonstra que, tendo o entendimento de ação dramática, podemos jogar com esta e construir uma sequência de acordo com o público que temos a nossa frente. É lógico que não encenávamos as peças de Soffredini assim; se havia cortes era depois de fazermos várias apresentações e ensaios e constatarmos a não eficácia da cena - só então ele a cortava. É interessante o exercício do desapego 
para a improvisação, fazer escolhas do que funciona ou não é um atributo vital ao palhaço.

Por fim, chegamos à forma do teatro popular, com seus tipos e convenções pragmáticas encontradas principalmente no circo-teatro, que Soffredini pesquisou para entender o teatro popular, aquele que se comunicou tão bem com variados públicos do país. Chegou a fazer comparações com outras formas e pesquisas que se debruçaram sobre o teatro popular: teatro de Brecht e teatro japonês, principalmente o Nô e o Kabuki.

Soffredini utilizava muito o expediente de atores entrarem e montarem a cena às vistas do público, como se estivéssemos em um picadeiro e colocássemos (e tirássemos) objetos com a agilidade de um partner ou acrobata, por meio de pequenos saltos, sempre olhando para o público e valorizando a ação, tornando o ato num pequeno espetáculo. Gostava de associar a uma figura do teatro japonês chamado koken, um contrarregra que colocava os objetos nas mãos dos personagens extremamente estereotipados sem serem notados, mas que todos viam. Essa forma mágica e altamente teatral, como ele dizia ser, deixava o público num estado de extrema atenção, o que mantinha esse público ativo durante a apresentação.

A importância que vejo nas questões referentes à forma estão ligadas ao palhaço no que diz respeito ao estudo da estereotipia adequada à linguagem na qual você/personagem investe para desenvolver sua ação dramática, sua vestimenta (ou máscara corporal, como escreverei a respeito mais à frente), seu gestual, sua verborragia, a construção de equipamentos e materialidades utilizadas nas entradas, reprises e esquetes. A forma manifesta o conteúdo.

O que Soffredini propunha era a essência de uma poética na qual se manifestasse "o teatro da magia teatral", que ele explicava assim:

Há uma imagem que a gente costuma repetir para tentar explicar e que é um jogo de perspectivas: Coloca-se um telão num palco. No telão está pintada uma estrada (em perspectiva), que começa no palco e acaba no horizonte lá longe, criando um espaço ilusório, dando uma sensação de profundidade. Na frente desse telão põe-se um ator. Ilumina-se esse ator. A sua sombra será projetada num telão, revelando a cortina de pano pintado que é o telão, revelando o espaço verdadeiro. O resultado é o seguinte: A gente vê a sombra em duas dimensões (a verdade) revelando o espaço verdadeiro, projetada sobre o telão da estrada em três dimensões (a mentira) revelando o espaço ilusório. Essas duas imagens se justapõem, se casam. E a gente acredita nas duas. É isso (SOFFREDINI, 1980, p. 4).

Outra experiência vital para minha formação de palhaço foi o intercâmbio feito com Neyde Veneziano, que, em 1985, havia 
dirigido o espetáculo O Noviço, de Martins Pena. Soffredini e Veneziano promoveram e ministraram um encontro entre os dois grupos, que participaram de uma oficina prática e teórica sobre Commedia dell'arte. Realizamos um trabalho intenso com as máscaras, que também imprimiram outra qualidade à nossa pesquisa sobre a estética popular.

Essa experiência no Núcleo ESTEP veio a se repetir e cristalizar-se em outro processo de montagem, que foi o da peça "Na Carreira do Divino", que agregou um forte trabalho musical, outra característica do teatro popular que desenvolvi ao longo do meu trabalho como palhaço. Retirei-me do Núcleo ESTEP em agosto de 1987.

Em resumo, fui altamente contaminado pelo processo de formação desenvolvido por um diretor pedagogo que investiu sua pesquisa estética na educação de jovens atores e atrizes, com o objetivo de aplicar os resultados de suas pesquisas teatrais anteriormente desenvolvidas em outro grupo de teatro: O Mambembe.

No início de 1988 resolvi me enveredar pelo caminho da direção teatral e convidei amigos do teatro da cidade São Bernardo do Campo a participarem de uma montagem do texto "Velório à Brasileira", de Aziz Bajur. Eu escolhi o texto porque oferecia uma estrutura de tipos muito interessantes e a dramaturgia me permitiria aplicar os conceitos que absorvi no Núcleo ESTEP.

Deparei-me com a mesma situação que Soffredini encontrou ao trabalhar com o elenco de "Minha Nossa": a falta de técnica e entendimento da linguagem que queria imprimir na montagem. Todos haviam trabalhado no teatro amador, mas em espetáculos de estética realista, para os quais as preparações basearam-se muito nos livros de Stanislavski e nos conceitos de quarta parede e fé cênica, e o que eu iria propor caminharia em direção contrária.

Nas leituras de mesa veio um entendimento político da tragicomédia em questão, que reforçou a necessidade de pesquisarmos expedientes de teatro popular. O primeiro ponto a ser abordado foi o estudo dos tipos que a peça propunha que, por conseguinte, encaminhava à pesquisa da forma.

A primeira dificuldade na pesquisa da forma foi a relação com o estereótipo: o elenco não estava instrumentalizado e nem familiarizado com uma forma tão extrapolada de personagem. Iniciou-se um processo de expansão do corpo cênico a partir do clown. Desenvolvi uma reprodução da oficina de Zigrino, por isso adotei o termo clown nas primeiras oficinas.

Como a montagem seguiria a direção que se apoiaria na colocação de tipos em cena e, na oficina que fiz com Zigrino, ele pediu para escolhermos um tipo, achei uma relação direta e fazíamos vários exercícios teatrais com nariz de palhaço, 
sendo que os primeiros derivamos de alguns expedientes de Stanislaviski: escrevemos as gêneses das personagens; fizemos atividades rotineiras das personagens (as mulheres faziam afazeres domésticos e os homens trabalhavam no departamento de águas e esgoto); fizemos jogos de fé cênica procurando um bilhete premiado da loteria como acontecia na peça etc.

Foram repassadas algumas técnicas de mímica, para instrumentalizá-los para esse jogo com afazeres da rotina das personagens; pedia que brincassem com o corpo por meio de exageros de movimentos que partissem de várias partes do corpo: olhar com o cotovelo, apontar algo com o queixo ou bunda, usar a alavanca de andar partindo do quadril etc. Fui encaminhando os trabalhos para afazeres mais lúdicos, como dançar numa festa, todos participarem de brincadeiras clássicas de crianças, praticarem algum esporte. O importante era que o clown agisse no corpo dos atores, que rompêssemos a barreira do realismo que aparecia sempre como um antagonista nas atividades.

Ainda sem ensaiarmos a peça, continuamos nossa pesquisa da forma na confecção dos figurinos e como o estereótipo poderia se potencializar nessa materialidade. Partimos de um estudo de unidade de frequência de cores com uma vibração bem alta, que poderia ser expressa até por estampas. Estudamos as deformações das personagens que poderíamos aplicar nos modelos das roupas.

Tive contato com esse procedimento no Núcleo ESTEP com o figurinista Irineu Chamiso Jr. ${ }^{5}$, que nos orientou no estudo da forma, partindo de uma palheta de cores que vibrassem no tom da encenação, e utilizamos vários figurinos e roupas que compunham o guarda roupa da Escola de Teatro da Fundação das Artes de São Caetano do Sul. Irineu pediu que trouxéssemos ao palco todas as peças de roupas que achássemos pertinentes, de alguma forma, para a encenação; que depois colocássemos essas roupas conforme a composição de nossas personagens e, em seguida, ficássemos numa fileira. Um a um, íamos até a plateia e víamos o resultado dessas escolhas.

Depois solicitou que fizéssemos ajustes colocando peças sobrepostas (ou subpostas) com cores e formatos que ajustassem o olhar coletivo e visão dos figurinos na encenação. Foi aplicada uma reprodução do procedimento até atingirmos o desejado pelo diretor e pelo figurinista. Foi uma pesquisa que revelou ao elenco a potência da estética na qual estávamos enveredando e, a partir deste procedimento, o grupo entendeu o que se configuraria na maquiagem, nos objetos de cena, na maneira de falar, na sonoplastia, na procura dos efeitos e a encontrar os momentos de triangulação.

Nessa primeira direção que desenvolvi, com muito pouca experiência (pois só havia sido assistente de direção de Soffredini
5 .

Irineu Chamiso Júnior (Santos SP 1949). Cenógrafo e figurinista. Destacado cenógrafo e figurinista dos anos 1970 e 1980, dedicado à pesquisa das fontes populares da visualidade nacional, colaborador do Grupo de Teatro Mambembe e de Antunes Filho. Tendo se iniciado no teatro amador em Santos, em 1968, acompanha o diretor e dramaturgo em seu deslocamento para São Paulo, atuando ao seu lado em algumas de suas criações. 
em "Minha Nossa"), eu me apoiei na cópia de ações deste diretor e também no que observei em Zigrino. Senti que não tinha apropriação completa dos métodos por total falta de experiência; tinha clareza das necessidades técnicas inerentes ao processo e percebi que teria que adaptar todas as ideias e ações a uma nova cultura de encenação.

Hoje, termos como "diretor de ator" ou "diretor pedagogo", definem melhor essa atitude de preparar atores e atrizes para encenações específicas, que experimentei como narrado acima, e acredito serem concWeitos ligados à oralidade. Partimos sempre de alguma experiência, seja observando ou vivenciando a aplicação de procedimentos de maneira dialógica (executando ipsis litteris) ou dialética (com adaptações), o que promove um processo cênico que gera novas matrizes de criação.

O espetáculo "Velório à Brasileira", que dirigi, participou de vários festivais de teatro. Dentro desse universo nos colocamos em posição de escuta de jurados e críticos, o que possibilita outro tipo de aprendizado, diferente daquele que acontece no contato direto com o público. Usando um jargão circense: "a peça agradava bastante".

As apresentações feitas para um público espontâneo nos davam uma impressão muito positiva de nosso trabalho, ao contrário de uma audiência formada por especialistas, da qual o retorno não era uma unanimidade em relação ao termo "agradar". No entanto, foram discussões muito interessantes acerca dos termos que pesquisei no Núcleo ESTEP e pratiquei no espetáculo. As questões estavam muito ligadas à estética popular e uma bruma de preconceitos e falta de entendimentos que envolvem as tentativas de tentar apropriar-se dos expedientes imbricados nessa estética. Surgiram comentários com teores que denotavam a superficialidade de entendimento da estética popular: "é tudo muito exagerado", "muito estereotipado", "é interessante esse olhar constante para com o público", "o ritmo é muito acelerado" etc. Naquela época eu tive a certeza de que estava agindo dentro da estética popular simplesmente por levar o espetáculo a favelas, sociedades amigos de bairro e sindicatos, e obter um retorno muito grande de comunicabilidade por meio dos tipos e da forma. 


\section{REFERÊNCIAS}

AVANZI, Roger \& TAMAOKI, Verônica. Circo Nerino. São Paulo: Pindorama Circus: Códex, 2004.

BOLOGNESI, Mário Fernando. Palhaços. São Paulo: UNESP, 2003.

PIMENTA, Daniele. Antenor Pimenta e o Circo-Teatro Rosário: uma história do Circo-Teatro no Brasil. Dissertação (mestrado em artes). São Paulo, ECA/USP, 2003.

PIMENTA, Daniele. A dramaturgia circense: conformação, persistência e transformações. Tese (doutorado em artes) UNICAMP, São Paulo, 2009.

AVANZI, Roger. Entrevista concedida para o projeto Clown ou palhaço, eis a questão - As várias faces desta máscara. São Paulo, 29 de agosto de 2011.

CARVALHO, Val. Entrevista concedida para o projeto Clown ou palhaço, eis a questão - As várias faces desta máscara. São Paulo, 27 de julho de 2011.

PIMENTA, Tabajara. Entrevista concedida para este trabalho. Ribeirão Preto, 13 de janeiro de 2014. 